\title{
THE LONG-TAILED FIELD MOUSE
}

By JoInN SANkey

(Assistant Warden, Juniper Hall Field Centre, Dorking, Surrey.)

The long-tailed field mouse or wood mouse, Apodemus sylvaticus, is found over nearly the whole of the British Isles. It is a variable species, and scientists have divided it into a number of sub-species, of which the type is very common in the Box Hill region of Surrey where I live. Another mouse which some specialists regard as a sub-species and which is known as the yellow-necked field mouse, $A$. flavicollis, is said to occur in the district though I have never seen one. It would be interesting to know more about the distribution of these mice and amateur naturalists could make useful observations on their ccology.

The long-tailed field mouse will eat almost anything of plant origin and during the cold weather of March this year we caught a large number in our house using a Longworth small-mammal trap which catches them alive and unharmed. The potatocs, greens and onions in the larder were the main objects of attraction. Unfortunately they have the annoying habit of sampling every potato in the box instead of just eating one. They also ate grapefruit skins. As bait we used bread, sweet and plain biscuits, and picces of cheese rind, and all seemed equally acceptable. The few specimens I have kept in captivity have thrived on dog biscuits and a little green plant food such as dandelion leaves and grass. I suspect they will also eat certain fungi and $I$ once found one of these mice dead beside the poisonous (at any rate to us) Amanita phalloides or Death Cap, which had been nibbled. Here again there is scope for observations by the amatcur naturalist.

I did not kecp a count of the total number of long-tailed field mice we caught indoors because my wife was also busily engaged in letting them go from time to time. But we did get fifteen during the last fortnight that they were coming into the house and on one occasion we caught three within as many hours in broad daylight. We let them go well away from the house but I suspect some of our captives had been in the trap more than once.

'The long-tailed ficld mouse is active all the winter and it usually stores the food that it gathers during the autumn. Seeds, nuts, acorns and bulbs arc among its favourite foods. No doubt some of the mice forget where they put their honrds, which in any case would probably get low towards the end of 
winter. After such a summer and autumn as we had last year when their harvest was probably poor, they would have run short of food by March and this, I suggest, may cxplain our invasion, though each year a few come indoors during the winter. Has anyone else had a large long-tailed field mouse invasion this winter?

In the garden this species can do much harm, especially amongst seed-beds of peas and beans. Not only will they seek out and eat the buried seeds but they will nip off the growing seedlings. In Kent I once saw a field of broad beans very badly damaged by long-tailed field mice. In fact the harm which they did warranted the farmer's ploughing in the remains of his crop and reseeding the field. I believe such damage is more often attributable to the bank vole, Clethrionomys glareolus, or the short-tailed field vole, Microtus agrestis. Both these are distinguished from the long-tailed field mouse by their very short tails and less pointed ears and are usually a much darker brown.

I once inadvertently destroyed a long-tailed field mouse's nest. But the occupants, parent and five babies, tumbled out on to the soft grass from the mass of litter which I wished to examine and had pulled out from the bottom of a hedge. Fortunately the young were at a fairly advanced stage of growth and were able somewhat awkwardly to scramble away to safety. Immediately after the accident the adult dived for the safety of the hedge bottom, making a high-pitched squeaking noise-obviously an alarm note. This continued until all the young had also reached the hedge and taken cover in the thick plant growth and leaves. I kept absolutely still and without hesitation the young immediately went in the direction of the parent's calling despite my having seattered them in all directions on the ground.

It is stated that there may be as many as five litters a year and that seven is the maximum number in a litter. The females are said to breed when they are five months old. I have not tested this with captive long-triled field mice but I would not be surprised if the figure were really much lower-perhaps three months. These mice are ensy to kecp in captivity and any naturalist could casily verify or amend this statement. But it is not difficult to sec why this is such a common species. Large and frequent litters are a corollary to a high mortality rate caused by stoats, weasels, foxes, kestrels, owls and other predators and this little mouse well illustrates this fundamental law of nature. 